\title{
Learning the Spanish Language for Ideological, Political, and other Curious Reasons
}

\author{
Prodani Anastasi \\ Universiteti i Tiranës, Albania \\ nastaprodani@yahoo.com \\ Gjinali Aida \\ Universiteti i Tiranës, Albania \\ aidaginali@yahoo.it \\ Gjoka Sandra \\ Universiteti i Tiranës, Albania \\ sandragjoka@gmail.com
}

\begin{abstract}
Spanish language and teaching it in Albanian schools did not come as a request of the labour market. It was made available only through the need and lunatic wishes of a dictator, who wanted to spread his words, his revolutionary ideas and the pattern of the building socialism in Albania according the lessons of Marxism-Leninism in the whole world, and in this case in Spanishspeaking world, either in Spain or Latin America. As a consequence, small but concrete steps were undertaken for the schooling and professional education of those who in the future would work as translators, radio presenters or teachers of Spanish language. The main purpose of this research is to highlight the itinerary followed by the Spanish language in the context of totalitarism in Albania from the '90s till nowdays.
\end{abstract}

Keywords: Spanish language, Marxist-Leninist members, communist propaganda, Spanish curriculum.

\section{Introduction.}

Trying to provide a panorama of the teaching of Spanish language in Albania is a privilege, but also a relatively important duty and responsibility. Thanks to the successful collaboration among generations, but also among university colleagues and other institutions, we were able to receive a material that has never been published before. The interviews and discussions, whether online or physical, are the main source of information that will be published in this study. The difficulty is time, memory that has erased fragments and names that belong to a 50 -year period. We should add to this variable the difficulty of the mentioned period, the totalitarian dictatorship or "dictatorship of proletarian", where intentionally or not, the mechanism of memory erasing has worked and becomes more evident in some areas of study. We are dealing with the years of the Cold War, where Albania firstly belonged to the Block of Eastern communist countries, and then, was transferred to the "building of socialism by relying entirely upon its own power". Without such a historic context, it is not possible to grasp the fate of Spanish language in Albania, "in this country, the lighthouse of Marxism-Leninism in the whole world, which laughs in the face of wolves".

The existence of the Spanish language in Albania is closely related to the mentioned communist period. Enver Hoxha, the leader of the Communist party, which was later renamed The Albanian Labour Party (PPSH), was in the same time the de facto government and state leader for nearly 40 years. Because of this, he was the writer of many books inspired from the Marxist-Leninist ideology and from the socialism pattern that was being applied in Albania. The obligation and his wish to spread this pattern of the socialist Albania brought forth the need for translating the works of Enver Hoxha in as many foreign languages as possible. It is worth mentioning the fact that in 1972, the Academy of Science was created, acting as the highest scientific institution, whose main objective was to support the socialism in Albania, being based on the principles of Marxism-Leninism, inspired by the Communist Party. For the same reason, in 1956 there was created an institution dedicated exclusively to the composition of the Albanian Labour Party history. From 1968 to 1990 this institution published all the works of Enver Hoxha and other communist politicians (Prodani A., 2013: 11). This is the general panorama whose 
immediate obligation, or if we take into consideration the terms used at that time, "the obligation of the party", was the translation of the Enver Hoxha works and his claims, even in Spanish.

\section{Nombres de guerra}

During that period, there existed only two publishing houses in Albania: Publishing House "Naim Frashëri", which dealt with fiction works' translation, and the Publishing House "8 Nëntori", which dealt with the translation Enver Hoxha's works and other translations of political aspect, and also, the publishing of two magazines in Spanish: "Albania Hoy" and "Albania Nueva", which were entirely dedicated to the propaganda of "victories and achievements of the socialist Albania", published once in two months and with a duration of some years.

Faced with this situation, there came the need and the necessity to educate people in Hispanic background. And where better than in Cuba? The only Spanish- speaking communist country. Therefore, in a bilateral agreement, in 1962 the first generation of Albanian young people was sent to be educated in Havana. This generation was composed of 2 young boys who studied there for 5 years.

The honourable professor Skënder Vuçini, who belonged to the second generation sent to Cuba in 1963, tells the following in an interview conducted on November $14^{\text {th }}, 2014,10.00$ am:

"The two boys who went to Cuba to get an education in 1962 are Ali Laho from the village of Peqin and Shezai Shyti from the village of Terbac in Vlore. At that time, they were both working as teachers in the village. The next year, in 1963, Perparim Sinani and me, just graduating from high school, went to Havana to study there and return to the country 5 years later, in February of 1969."

But Cuba was not the only country that welcomed Albanian youngsters. Two other generations were sent in the distant communist China to be educated in Hispanic studies. Professor Fatmir Xhaferi, who actually works as professor of Spanish language in the faculty of Foreign Languages, graduated in the University of Beijing. In an interview conducted on December $3^{\text {rd }}, 2014$, at $01.00 \mathrm{pm}$, tells:

"I was an excellent student of medicine. I adored it and the thought of learning a foreign language never crossed my mind. They simply told me they had decided for me to go to China. In the period of 1974-1978, the time of my studies in China, it was out of the question to object what the system decided for you. So, together with Professor Hamdi Dega, we became the second and the last generation sent to China. Later, the relationship between both countries was interrupted."[We would like to remind here that two other young students who graduated in China were Ivzi Koçi and Tasim Kokona]

After the return of the young people in Albania, they were immediately employed in the only publishing house at that time, with the duty of translation or editing, even in Radio Tirana, the first radio station in Albania. Others were employed in the Central Committee of the Party, in ATA or in the Ministry of Foreign Affairs.

In the middle of the "70s, the first Spanish contingent came in Tirana. They were a couple and lived in the "German villas". Both of them worked and gave their contribution in the publishing houses and also in Radio Tirana. The objective this time remained the same: to transmit news and successes of Albania to the whole world. At the time, there were prepared separate radio programs for Spain and Latin America. The duration was one hour. The Spanish people edited the materials translated by translators-understudy and radio speakers at the same time.

When questioned in an interview performed by the translator Elvi Sidheri with the Spanish writer and journalist who visited Tirana in 1974, José Catalán Deus told that he was part of the National Anti-fascist Revolutionary Frontier (NARF). He himself was a fan and supporter of the communist propaganda and at the time NARF used to make propaganda for the communist regime of Hoxha in Albania (Sidheri E., 2014).

All the foreigners, including Spanish and those of Latin America, were communists with Marxist-Leninist belief, and they visited Albania as guests officially invited by the Albanian government. They were part of the Marxist-Leninist Communist parties or NARF, that is, extreme left wing groupings. They used nicknames, "nombres de guerra", or "war names", and not their real names. Very often, when visiting Albania, they changed the war names they used in Spain. They worked as professors of Spanish language, they prepared news or edited them, they corrected the texts translated into Spanish from 
Albanian, and also hosted radio programs. There we also people like Ramon Sanchez Lizarralde who engaged in fiction translation, mainly works of Ismail Kadare. Their activity and engagement lasted for a certain period of time (generally 2 to 4 years), then later they went back to their country and were replaced by other incoming couples. They were part of the propaganda machinery of the communist regime, as well, to transmit the voice and successes of the socialist Albania in the world. It was not a rarity for them to attend the School of the Party ${ }^{1}$ and listen to lectures on Marxism-Leninism. (The School of the Party was attended by future leaders of the new socialist system who were educated on an ideological and political background. The axis of the education was the Marxism-Leninism ideology.)

Table 1 represents data on the Spanish contingent; the first table provides the war names; the second, their real names and the last one their occupation in Tirana. Some data are missing due to lack of information and in the table there are represented 12 couples. The information has been gathered thanks to the consultancy of María Roces González, Ma Antonia Garcia (Clara) and Jesús Hernández (Andreu), Elsa Bakshevani, Ivzi Koçi, Skënder Vuçini and Fatmir Xhaferi.

\section{Table 1}

Members of FRAP (Frente Revolucionario Antifascista Popular)², CP (marxist-leninist) of Spain, [PCE (m-l)], who worked at Radio Tirana, at the Publishing House "8 Nëntori", at the High school of foreign languages "Asim Vokshi" and at the University of Tirana.

\begin{tabular}{|c|c|c|c|c|c|c|}
\hline $\mathrm{n}^{0}$ & Period & $\begin{array}{l}\text { War nicknames } \\
\text { used in Albania }\end{array}$ & Real names & Members of & Observations & Employee of... \\
\hline 1 & 1965-1970 & Luis Buhalance $^{3}$ & $?$ & PCE(m-l) & $\begin{array}{l}\text { Member of Central } \\
\text { Comitty of th CP of } \\
\text { Spain PCE (m-l) }\end{array}$ & Radio Tirana \\
\hline \multirow[t]{2}{*}{2} & 1970-1974 & Guillermo & Pedro & PCE(m-l) & & Radio Tirana \\
\hline & $1970-1974$ & Elena & $?$ & PCE(m-l) & & Radio Tirana \\
\hline \multirow[t]{2}{*}{3} & $\begin{array}{l}\text { February } \\
\text { 1974- } \\
\text { February } 1976\end{array}$ & Antonio & José Catalán Deus & PCE(m-l) & & $\begin{array}{l}\text { Radio Tirana \& } \\
\text { Publishing House "8 Nëntori", \& } \\
\text { Spanish lessons at Radio Tirana }\end{array}$ \\
\hline & $\begin{array}{l}\text { February } \\
\text { 1974- } \\
\text { February } 1976\end{array}$ & Beatriz & Dolores (Lola) Galán & $?$ & & P. H "8 Nëntori" \& Radio Tirana \\
\hline \multirow[t]{2}{*}{4} & $1975-1980$ & Juan & Benjamín Padilla & PCE(m-l) & $\begin{array}{l}\text { Replaced } \\
\text { J. Catalán y Lola } \\
\text { Galán }\end{array}$ & P. H. "8 Nëntori” \& Radio Tirana \\
\hline & $1975-1980$ & Clara & $\begin{array}{l}M^{\mathrm{a}} \text { Antonia García } \\
\text { Sanz }\end{array}$ & PCE(m-l) & & Radio Tirana \\
\hline \multirow[t]{2}{*}{5} & $\begin{array}{l}\text { 1977- October } \\
1980\end{array}$ & Victor & $?$ & PCE(m-l) & & Radio Tirana \\
\hline & $\begin{array}{l}1977- \\
\text { October } 1980\end{array}$ & Rosa & $?$ & PCE(m-l) & & Radio Tirana \\
\hline \multirow[t]{2}{*}{6} & 1979-1983 & Pablo & $?$ & PCE(m-l) & $\begin{array}{l}\text { Replaced } \\
\text { Juan y Clara }\end{array}$ & Radio Tirana \\
\hline & 1979- 1983 & María & $?$ & PCE(m-l) & & High school "Asim Vokshi" \\
\hline \multirow[t]{2}{*}{7} & $\begin{array}{l}\text { October 1980- } \\
\text { April } 1984\end{array}$ & Karlos Sanchez & $\begin{array}{ll}\begin{array}{l}\text { Ramón } \\
\text { Lizarrade }\end{array} & \text { Sánchez } \\
\end{array}$ & PCE(m-l) & $\begin{array}{l}\text { Replaced } \\
\text { Victor y Rosa }\end{array}$ & P. H. "8 Nëntori \& Radio Tirana \\
\hline & $\begin{array}{l}\text { October 1980- } \\
\text { April } 1984\end{array}$ & Karmen Gonzalez & $\begin{array}{ll}\text { María } & \text { Roces } \\
\text { González } & \end{array}$ & PCE(m-l) & & $\begin{array}{l}\text { Radio Tirana \& Spanish lessons at } \\
\text { Radio Tirana }\end{array}$ \\
\hline 8 & 1983-1986 & Pepe & Rafa Lluch & PCE(m-l) & Replaced & Radio Tirana \\
\hline
\end{tabular}

2 http://www.march.es/ceacs/biblioteca/proyectos/linz/documento.asp?reg=r-9533

3 PCE (m-l) was founded by October-December 1964 and right-away sent its members work at the broadcasts of Radio Tirana. The mail of PCE $(\mathrm{m}-\mathrm{I})$ came to the Spaniards of Radio Tirana always in the name of Luis Buhalance. 
ISSN 2411-9563 (Print)

ISSN 2312-8429 (Online)
European Journal of Social Sciences Education and Research
January-April 2015

Volume 2, Issue 1

\begin{tabular}{|l|l|l|l|l|l|l|}
\hline & & & & & Pablo y María & \\
\hline & $1983-1986$ & Lola & & PCE(m-l) & & $\begin{array}{l}\text { High school "Asim Vokshi" \& Radio } \\
\text { Tirana }\end{array}$ \\
\hline 9 & $\begin{array}{l}\text { April 1984- } \\
1987\end{array}$ & Andreu & Jesús Hernández & PCE(m-l) & $\begin{array}{l}\text { Replaced } \\
\text { Karlos y Karmen }\end{array}$ & $\begin{array}{l}\text { P.H. "8 Nëntori", Radio Tirana \& } \\
\text { Tirana University }\end{array}$ \\
\hline & $\begin{array}{l}\text { April 1984- } \\
1987\end{array}$ & Ana & Margot Coria & PCE(m-l) & & Radio Tirana \\
\hline 10 & $1986-1988$ & Eduardo & Ángel Yébenes & PCE(m-l) & $\begin{array}{l}\text { Replaced } \\
\text { Pepe y Lola }\end{array}$ & Tirana University \\
\hline 11 & $1987-1989$ & Ramón1 & Ramón & PCE(m-l) & $\begin{array}{l}\text { Replaced } \\
\text { Andreu y Ana }\end{array}$ & Radio Tirana \\
\hline & $1987-1989$ & Adela & Adela & PCE(m-l) & & Radio Tirana \\
\hline 12 & $1988-1990$ & Juanjo & Juanjo & PCE(m-l) & The last ones to leave & Radio Tirana \& Tirana University \\
\hline & $1988-1990$ & Pilar & Pilar & PCE(m-l) & & Radio Tirana \\
\hline
\end{tabular}

Apart from the Spanish marxist-leninists, there were others from various countries working at Radio Tirana. All these marxist-leninists were housed initially at Aviation Apartment Buildings and then they were all transferred to live at the Germans' Villas/Compound.

At the beginning, mthere were three 30 minute radio-broadcasts in Spanish: one for Spain, mone for Latin America and a joint one for both. Later, there were run two 1hour broadcasts: one for Spain and one for Latin America. The broadcast programme started: "Habla Tirana. Habla Tirana. Están en sintonía de radio Tirana..." and the programme was accompanied with the play of International's Anthem.

"Albania Nueva" was an illiustrated political \& social magazine. It was published twice a month in Albanian, Spanish, German, Arabic, French, English, Italian and Russian. Editorial address was: "Shqipëria e Re", Rruga "Themistokli Gërmenij" 6, Tirana, Albania. It contained articles on the planned economy, Congresses of the Party and of the Socialist Women, on People's Army, health service, polit bureau, articstic-cultural life (parade of 1st May, May concerts, movie festicals), handicraft, as well as short artistic writings in prose and poesy; segments from the history and geography of Albania. Photos were produced by ATA (Albanian Telegraphic Agency).

Furthermore, other marxist-leninists, although less in numbers, came from Latin America to work at Radio Tirana.

1. The Peruian Felix was provided also with a residence permit

2. After the coup d'etat in Chile, Raul from Chile came for a period of 6 months to find refuge in the country.

3. A couple of Chileans with two children, named Mario and Jimena.

4. A couple of Colombian, Marsela and Dario with three children resided for 4 years.

According to the interview conducted by E. Bakshevanit, Radio Tirana broadcasted in 20 foreign languages, apart from Albanian targeting Albanians living abroad. These broadcasts were in the following languages: Chinese, Arabic, Turkish, Serbo-Croatian, Polish, Czech, Hungarian, Romanian, Italian, Portuguese, Indonesian, English, French, German, Swedish, Spanish, Persian, Russian, Greek and Bulgarian.

To attend the Party's School, the requirement was to have graduated the high school and be a party member. This school trained the young cadres for party secretaries, etc.

On the other side, other Albanian young people, who had graduated on Albanian Language and Literature, attended a second three-year school, of 12 hours of lessons per week, in the premises of Radio Tirana, to learn the Spanish language, taught by the Spanish people visiting Tirana. Radio Tirana was at the time one of the European radios, which transmitted more foreign language programs, more than twenty languages, in different timetables and frequencies for Spain and Latin American (Sidheri, 2014).

\footnotetext{
${ }^{1}$ The last couples did not use any longer the war nicknames as SCP (m0I) ewas legalised in Spain in 1981.
} 
In the below interview conducted on November $11^{\text {th }}, 2014,03.00 \mathrm{pm}$, the translator, and, at the same time, the first speaker of Spanish language in Radio Tirana, Elsa Bakshevani, reminisces:

"I had just graduated in Albanian Language and Literature. Together with my friend from university, Rina Hasani, we were asked to become radio speakers and broadcast news in Spanish. We started learning Spanish with native speakers. Some of them were teachers of Spanish language, some were not. But they were native speakers, as well. It was important to learn the language."

Before the employment of E. Bakshevani, R. Hasani and Kristofor Ndreu, two other employees worked at the Radio, Niko Redi and Leo Prela, who did not have the proper academic education, but had learnt Spanish when they were emmigrants in Latin America. The first one was in Mexico.

What happened to the young people that were educated in Cuba and China? As it was mentioned above, they were employed in both publishing houses and in Radio Tirana. Professor Skënder Vuçini, in continuance of his interview, adds:

"Ali worked at the Radio. Shezai was sent to the Central Committee. From 1972-1974 I worked in the Radio as professor. I corrected the speakers' errors. The news was registered before being aired. So, the news in Radio was not aired live. Besides Radio Tirana, I worked in the publishing house, as well. My first translation, directly after my return to Albania in 1969, was the work of Enver Hoxha titled "The Story of the Albanian Labour Party". Moreover, Professor Ivzi Koçi, Hamdi Dega ${ }^{1}$ and Fatmir Xhaferi who graduated in China, worked as translators of Spanish language in publishing houses." [H. Dega has worked until the end of the " 80 s in the Albanian News Agency (ANA)]

With regards to these issues, Professor Fatmir Xhaferi adds:

"I was employed in the publishing house "8 Nëntori". I worked there for 16 years. After 16 years, the editorial office of foreign languages was closed. We used to work 36 people that translated all the works of Enver Hoxha. We translated it from Albanian into different languages."

\section{Spanish as a "rare language"}

By the middle of the '70s, there was an unsuccessful attempt to open a branch of Hispanic studies following the arrival of the professor José Catalán Deus, but it would be the year 1979 the one that would indicate the opening of the Spanish branch in the foreign languages high school "Asim Vokshi", where, besides Spanish, there were also opened branches of German and Italian. These three languages were labelled at the time as "rare languages". Maybe it was due to the low number of students or due to the low number of study rights, compared to the allowed places for English, Russian or French; or maybe because these languages were not known in Albania, or perhaps in the context of third languages, the new ones were considered a minority, because the minimum number of students was 8 per class. Spanish language teaching lasted only for a four-year period in the high school. The last generation was in 1983. In four years there were a total of 35-40 students (Archive of Asim Vokshi, 1979- 1983).

With regards to teaching, professor Skënder continues:

"I graduated in Hispanic Language and Literature in Cuba. With the opening of the Spanish branch in "Asim Vokshi" I taught Spanish Literature, History and Syntax. [?]"

Professor Fatmir adds:

"I was assigned as teacher of Spanish language in "Asim Vokshi" high school in 1979. It was my first time as a teacher. In the beginning, I raised my voice on the issue of lacking books. This concern was supported, enabling thus students to be supplied with books from my personal library and from that of the Spanish people working in the radio. In this way, students were supplied with books."

Although the beginnings of the Spanish language were difficult, it is worth mentioning the fact that before the '90s, the policy applied for foreign languages was the centralized one, based on the 5-year plan of the Party, as it happened with everything else in the economic-social-political Albanian life during the totalitarian period. 


\section{A forced "marriage": Spanish- Russian}

Spanish started in 1979 as an independent branch in the foreign language high school "Asim Vokshi", where there was studied only one foreign language; the Spanish experience lasted 4 years; it was terminated in 1983, and re-opened in 1990. The trajectory of Spanish in the high school "Asim Vokshi" has its own ups and downs, but it was always on the move and it was not absent for a long time. Whereas for it being included again in the university level, in the Faculty of Foreign Language, it had to wait for nearly two decades.

In 1999 it is offered within the bilingual package, together with Russian language. Students studied Spanish and Russian at the same time. Even after the ' $90 \mathrm{~s}$, what could not be achieved by the Labour Party, was achieved by the leading rings of the education institution, that together with the centralizing and planning policies, inherited from the past, united Spanish and Russian, with the purpose of keeping alive the Russian one in the pre-university system. Spanish, being the attractive and trendy language for the young, was "married" to the Russian that was considered as old-fashioned and lacked employment perspective for the youth. During the interview conducted with regards to this issue on November $10^{\text {th }}, 2014$, 1.20 pm, with the Spanish teacher Nertila Buçpapa at "Asim Vokshi" high school, she reminisces:

"The Spanish-Russian branch was opened in 1999. This branch lived for 10 years, as the last generation dates in the academic year 2008-2009. From 2009 up to now, we offer the branch Spanish-English."

Nowadays, in this high school of linguistic profile, Spanish and Russian are "divorced". Two other linguistic couples are available: Spanish-English and Russian-English. Thanks to the possibilities of chosen subjects and languages offered by the school, students are free to choose other languages according to their preference, despite what they are studying. Nertila presents actual available data of the academic year 2014-2015.

"Spanish as primary language is taught 4 hours per week. 112 pupils learn it as a primary language, 128 as a third one, because it is not offered as a second language. 60 students have chosen it as an advanced language, 37 pupils participate in the translation subject and 36 other in the Civilization one, which are specific subjects and are offered for an advanced level [it refers to X, XI and XII classes]. "

Questioned on the request-offer balance with regards to the quotes published by "Asim Vokshi" high school to start the preuniversity cycle, she replies:

"There are published approximately 40 or 80 quotes. This is decided by the school principal depending on the available classes. Pupils are selected based on the average marks of the elementary school. There is no other additional acceptance exam."

\section{5. "The new nest" for Spanish language in Albania}

In 2005 Spanish language is included in the curriculum of the Faculty of Foreign Languages as a subject of choice and three levels are offered according to the Common European Framework of Foreign Languages. In the beginning of the academic year 2007-2008, the Spanish government collaborated by sending one Spanish lecturer in the framework of the Program for Lecturers AECID. Later, in September of the academic year 2008-2009, the Spanish branch is opened in bachelor studies "Hispanic Language, Literature and Civilization" within the Department of Italian language. These steps were gradual and came as a need of time. While Spanish was in its first steps, in January 2009, the Department of Spanish language was suddenly opened by a decision of the Prime Minister of that time, Mr. Berisha, and the first Spanish ambassador in Tirana, Mr. Montobio. At that time there were only two Albanian professors and one Spanish lecturer, who worked full time in the department.

In such a situation, in 2009, the Spanish government, in collaboration with the Spanish department and the intermediation of the Spanish embassy in Tirana, designed a CAP project, through which professors of the 8 best Spanish universities came to assist the consolidation of the Hispanic studies. Thanks to the intermediation of the International University Menendez Pelayo the collaboration with the following universities became possible: Universidad Complutense de Madrid, Universidad Autónoma de Barcelona, Universidad de Salamanca, Universidad de Oviedo, Universidad de León y Universidad Nacional de Educación a Distancia (UNED), and three main fields of the study programs were covered: Language, Culture (literature and history), and the Spanish language didactics. Besides training the professors and lecturing the students, work was done to compile the teaching manuals of each subject, which was a novelty for the Faculty of Foreign languages. Moreover, great attention was paid to extracurricular activities directly or indirectly linked to students or academic circles related to Spanish language. As a consequence, in November 2009 the theatre group of the department 
was created; it has done many theatrical performances and has participated in the Festival of the university theatre of foreign languages in Macedonia, UNIFEST. In the academic year 2011-2012, in the Spanish department, began the bachelor studies in "Intercultural and Touristic Language and Communication" (Prodani, 2014). Today, there are approximately 340 students studying Spanish as primary and secondary language at the department of Spanish language. Respectively, 210 students attend the studies in the first Cycle; 50 others in the second Cycle of the Master studies and approximately 70 people study Spanish as a secondary language. From the academic personnel, 9 are full time professors, 4 are part time and there is one Spanish lecturer.

Outside the auditorium, Spanish language had a home of its own. In 1997 "Casa de España" (Spain's house) is opened in Tirana, which was preceded by the opening of the society "Amigos de España" (Spain's friends) (in the end of 1996), where, besides organizing courses of Spanish language and culture and different cultural activities, served as a consulate for many years until the opening of the Spanish embassy in Tirana. In May 2003, Casa de España is given another function. It is transformed in the centre of checking the DELE exams.

But this cultural centre would be closed due to the recent worldwide economic crisis that overtook Spain as well, and as a consequence dramatically reduced cost related to the expansion of Spanish culture and language. Such a hit was felt in the radius of Spanish expansion in Albania. In 2013, Casa de España was closed, concentrating thus the activities only in schools and universities. Meanwhile, Casa de España, has its own virtual life by opening a page in the social network "Facebook", which is used to share materials and information related to the Hispanic world. Now, it is the Department of Spanish language that is transformed in the examining centre of DELE exams, starting from 2013. Although in February $18^{\text {th }}, 2009$, the Ministry of Education ordered the use of Spanish in the list of chosen subjects in the A-level exams in Albania, it is not included in the pre-university system yet, as it has happened with Italian, French or German, as subject of free choice.

\section{Conclusions}

The Spanish language has a lifespan of over 50 years in Albania despite the short and long gaps in the auditors, its ups and downs, which came as a result, sometimes of ideological reasons and sometimes of political ones. It is important to emphasise that Spanish today is gaining every day more and more ground between younger generations and this requires a wise policy and a great support to make possible the introduction of Spanish language in the compulsory and high schools, just like other languages, such as German, French and Italian.

\section{References}

\section{Interview}

[1] Bakshevani E., Interview on 11.11.2014, hour 15:00 by Sandra Gjoka.

[2] Buçpapa N., Interview on 10.11.2014, hour 13:20 by Sandra Gjoka.

[3] Vuçini, Skënder. Interview on 14.11.2014, hour 10:00 by Sandra Gjoka.

[4] Xhaferi, Fatmir. Interview on 3.12.2014, hour 13:00 by Sandra Gjoka.

[5] Maria Roces Gonzalez, Email of January 7, 2014

\section{Archive materials}

[1]Spanish Department Archive, Faculty of Foreign Languages, UT, Registries and reports of 2014- 2015.

[2]"Asim Vokshi" high school Archive, Registries and reports checked by the documents of 1979- 1983.

http://www.march.es/ceacs/biblioteca/proyectos/linz/documento.asp?reg=r-9533 